\title{
PENGARUH KECEMASAN MATEMATIS TERHADAP HASIL BELAJAR MATEMATIKA SISWA
}

\author{
Muhamad Ikhsan \\ Universitas Muhammadiyah Sukabumi \\ pos-el : ikhsanicang9@gmail.com
}

\begin{abstract}
ABSTRAK
Penelitian ini bertujuan untuk mengetahui pengaruh kecemasan matematis terhadap hasil belajar matematika. Metode penelitian yang digunakan dalam penelitian ini adalah metode penelitian kuantitatif dengan tujuan untuk menguji hipotesis yang telah ditetapkan dan desain penelitian yang digunakan yaitu penelitian korelasional. Teknik pengambilan sampel yang digunakan adalah cluster random sampling yang menghasilkan kelas X IPS 1 di SMA Negeri 1 Cisaat menjadi subjek penelitian dengan sampel berjumlah 30 siswa dari populasi 120 siswa. Instrumen yang digunakan adalah instrumen tes hasil belajar matematika dan instrumen angket kecemasan matematis. Uji instrumen berupa validas isi, validitas, reliabilitas, daya pembeda, dan tingkat kesukaran. Metode pengumpulan data dilakukan melalui tes dan angket. Teknik analisis data yang dilakukan adalah analisis skala likert dan uji analisis regresi linear sederhana. Berdasarkan analisis regresi linear sederhana diperoleh $y=162,50-1,80 x$ yang artinya nilai $a$ sebesar 162,50. Nilai ini mengindentifikasikan bahwa bila tidak terdapat kecemasan matematis maka nilai hasil belajar matematika sebesar 162,50 . Nilai $b$ sebesar $-1,80$ artinya setiap penambahan $1 \%$ tingkat kecemasan matematis maka hasil belajar matematika akan menurun sebesar 1,80, begitupun sebaliknya. Karena koefisen regresi bernilai negatif, hasil tersebut menunjukan adanya pengaruh negatif antara kecemasan matematis siswa terhadap hasil belajar matematika siswa.
\end{abstract}

Kata kunci : kecemasan matematis dan hasil belajar matematika

\section{ABSTRACT}

This research is aimed to identify the effect of mathematics anxiety towards mathematics learning outcomes. The method used in this research is quantitative research method which is purposed to examine the decided hypothesis, and research design used is correlational research. Sample collection technique used is cluster random sampling which resulted Class $X$ SOCIAL SCIENCE 1 in SMA Negeri (State Senior High School) 1 Cisaat became the research subject within samples counted 30 students from the population counted 120 students that was divided to four classes. The instrument used in this research is an instrument to test mathematics learning outcomes and an instrument in the shape of mathematics anxiety questionnaire. The instruments were tested by validating the content validity, the validity, the reliability, the discrimination index, and the difficulty index. Data collection method was carried out through the test and the questionnaire. Data analysis technique which was carried out was Likert Scale analysis and test for simple linear regression analysis. Based on simple linear regression analysis, $y=162.50-1.80 x$, which means a value of 162.50. This value identifies that if there is no mathematical anxiety, the value of mathematics learning outcomes is 162.50. B value of -1.80 means that every $1 \%$ increase in the level of mathematical anxiety, the mathematics learning outcomes will decrease by 1.80 , and vice versa. Because the regression coefficient is negative, these results indicate a negative influence between students 'mathematical anxiety on students' mathematics learning outcomes.

Keywords : mathematics anxiety and mathematics learning outcomes 


\section{PENDAHULUAN}

Pentingnya belajar matematika tidak terlepas dari peranannya dalam berbagai kehidupan, misalnya berbagai informasi dan gagasan banyak dikomunikasikan atau disampaikan dengan bahasa matematis serta banyak masalah kontekstual dapat disajikan ke dalam model matematis.

Sesuai dengan pendapat Turmudi (2008: 3) bahwa matematika berkaitan erat dengan kehidupan sehari-hari sehingga dengan segera siswa akan mampu menerapkan matematika dalam konteks yang berguna bagi siswa, baik dalam kehidupannya ataupun dalam dunia kerja. Selain itu, mempelajari matematika dapat membiasakan seseorang berpikir kritis, logis, serta dapat meningkatkan daya kreativitasnya.

Hasil belajar matematika sangat penting, pentingnya untuk mengukur apakah pembelajaran yang selama ini dilakukan berhasil atau tidak.Menurut Dimyati dan Mudjiono (2013: 3) hasil belajar merupakan hasil dari suatu interaksi tindak belajar dan tindak mengajar. Namun, tidak sedikit siswa yang mengalami masalah dalam mengikuti kegiatan belajar mengajar pada mata pelajaran matematika sehingga berakibat kepada rendahnya hasil belajar matematika siswa. Berdasarkan hasil wawancara dengan salah satu guru di SMA Negeri 1 Cisaat mengatakan bahwa hasil dari ujian harian di kelas $X$ IPS rerata siswa mendapatkan nilai 59,50 dari KKM 65,00 untuk semua materi mata pelajaran matematika. Dengan demikian, hasil belajar matematika kelas X IPS di SMA Negeri Cisaat 1 Cisaat masih rendah.
Hubungan antara kecemasan dengan hasil belajar menurut Ashcraft (2002: 56) dapat dijelaskan dengan logika bahwa ketika seseorang memiliki kecemasan, maka memunculkan dalam tes dan memberikan hasil yang tidak maksimal. Hal ini sejalan dengan pendapat Sieber (dalam Sudrajat, 2008:1) menyatakan bahwa kecemasan dianggap sebagai salah satu faktor penghambat dalam belajar yang dapat mengganggu kinerja fungsi-fungsi kognitif seseorang, seperti dalam berkonsentrasi, mengingat, pembentukan konsep dan pemecahan masalah.

Berdasarkan hasil penelitian yang dilakukan sebelumnya oleh Widyastuti (2007: 2) yang salah satu tujuannya adalah untuk mengetahui ada atau tidaknya pengaruh yang signifikan antara kecemasan menghadapi tes matematika terhadap hasil belajar matematika. Hasilnya menunjukan bahwa hasil belajar matematika siswa yang mempunyai kecemasan menghadapi tes matematika tinggi lebih buruk dibandingkan dengan siswa yang mempunyai kecemasan menghadapi tes matematika rendah.

Rendahnya hasil belajar siswa bisa disebabkan oleh beberapa faktor, salah satunya yaitu siswa mengalami kecemasan belajar. Berdasarkan hasil wawancara yang dilakukan kepada salah satu guru matematika di SMA Negeri 1 Cisaat mengungkapkan bahwa siswa kelas X IPSkurang aktif dalam mengikuti kegiatan belajar di kelas,siswa jarang bertanya pada saat kegiatan belajar mengajar berlangsung, ketika siswa diminta untuk mengerjakan soal di depan kelas siswa terlihat panik dan gugup, ketika ada siswa yang 
mengerjakan soal di depan kelas siswa tersebut tidak yakin dengan jawaban yang dikerjakan, hal tersebut menunjukan bahwa kelas $\mathrm{X}$ IPS mengalami kecemasan dalam mempelajari matematika.

\section{METODE PENELITIAN}

Adapun teknik pengumpulan data yang dilakukan dalam penelitian ini dilakukan melalui tes, angket/kuesioner, wawancara, dan observasi. Pengolahan dan analisis data statistik deskriptif dimaksudkan untuk mencari kuatnya pengaruh antara variabel melalui analisis regresi. Adapun skala pengukuran kecemasan matematis yang digunakan dalam penelitian ini yaitu skala likert. Jumlah skor tersebut dimasukan ke dalam garis kontinum, yang pengukurannya ditentukan dengan cara:

Skor Kecemasan Maksimal : $\quad$ Skor Tertinggi $\mathrm{x}$ jumlah Soal $\mathrm{x}$ Jumlah Sampel

Skor Kecemasan Minimum : $\quad$ Skor

Terendah x Jumlah Soal x Jumlah Sampel Persentase Skor : (Total Skor : Nilai Maksimal) x 100.

Statistik uji yang digunakan untuk analisis statistik dalam penelitian ini yaitu analisis regresi linear sederhana. Analisis regresi linear sederhana adalah alat analisis yang digunakan untuk mengetahui besarnya pengaruh variabel independent (X) terhadap variabel dependent (Y). Dalam penelitian ini metode analisis regresi linear sederhana digunakan untuk mengetahui pengaruh kecemasan matematis terhadap hasil belajar matematika. Persamaan umum regresi linear sederhana adalah:

$$
y=a+b x
$$

Kererangan :

$y=$ nilai yang diprediksikan

$a=$ konstanta atau bila harga $x=0$

$b=$ koefisien regresi

$x=$ nilai variabel independen

\section{HASIL DAN PEMBAHASAN}

Hasil angket kecemasan matematis siswa kelas X IPS 1 dapat disimpulkan bahwa dari 30 siswa, 1 siswa mengalami kecemasan rendah, 23 siswa mengalami kecemasan sedang, dan 6 siswa mengalami kecemasan tinggi.

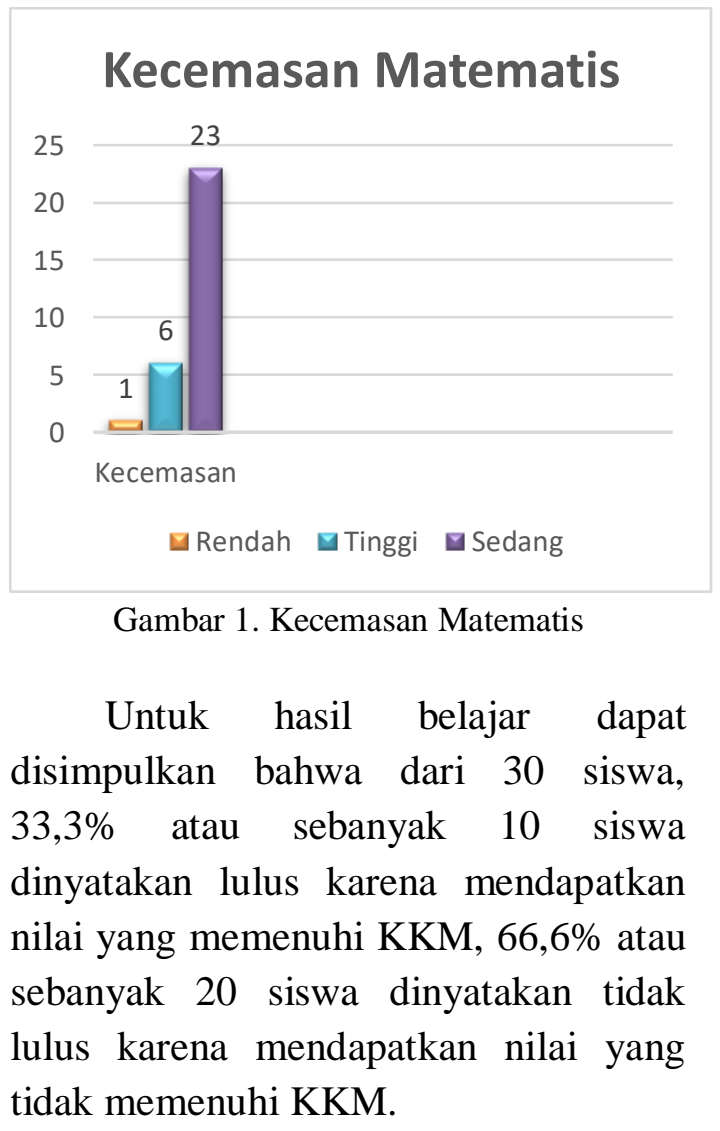




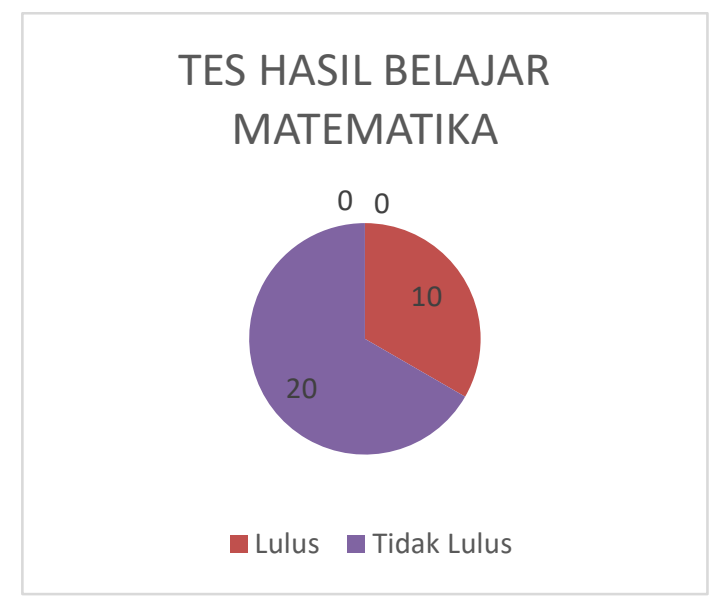

Gambar 2. Tes Hasil Belajar Matrematika

Dari hasil analisis regresi linear sederhana antara kecemasan matematis dengan hasil belajar matematika diperoleh persamaan regresi linear sederhana yaitu $y=162,50-1,80 x$. Dari model persamaan regresi tersebut dapat dijabarkan bahwa nilai $b$ sebesar $-1,80$ artinya setiap penambahan $1 \%$ tingkat kecemasan matematis $(\mathrm{X})$ maka hasil belajar matematika (Y) akan menurun sebesar 1,80, begitupun sebaliknya. Nilai $a$ sebesar 162,50 , nilai ini mengindentifikasikan bahwa bila tidak terdapat kecemasan matematis (X) maka nilai hasil belajar matematika (Y) sebesar 162,50. Nilai hasil belajar matematika (Y) sebesar 162,50 memang melebihi nilai hasil belajar maksimal yaitu 100 , namun nilai 162,50 tersebut tidak mungkin ditemukan karena kecemasan matematis (X) tidak mungkin 0 .

Karena koefisien regresi bernilai negatif, hasil tersebut menunjukan adanya pengaruh negatif antara kecemasan matematis $(\mathrm{X})$ terhadap hasil belajar matematika (Y). Untuk lebih jelasnya ditunjukan dalam diagram scatter dibawah ini :

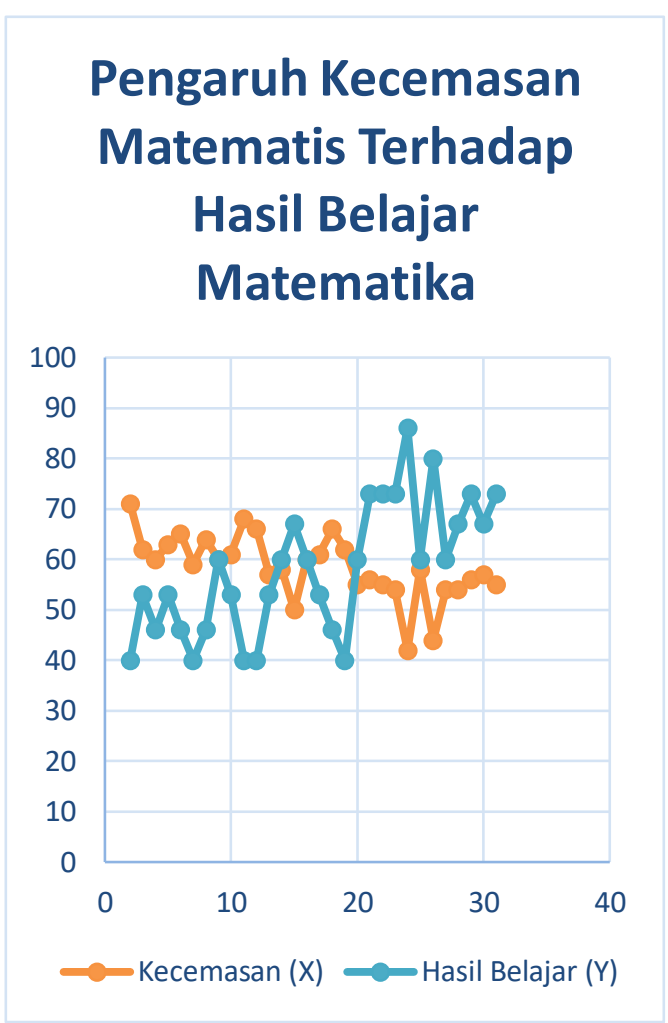

Gambar 3. Pengaruh Kecemasan Matematis terhadap Hasil Belajar

Analisis regresi linear sederhana dapat dilanjutkan dengan menghitung korelasi pearson, tujuannya untuk meyakinkan bahwa terdapat hubungan antara kecemasan matematis terhadap hasil belajar matematika. Dari hasil perhitungan uji korelasi pearson diperoleh nilai $r=-0,865$ menunjukan pengaruh sangat kuat dengan posisi tebaran tidak beraturan atau tidak linear. Arah hubungan negatif, yang berarti semakin tinggi kecemasan siswa, maka hasil belajar siswa rendah, begitupun sebaliknya.

Perhitungan dilanjutkan dengan menghitung koefisien determinasi, dengan cara mengkuadratkan koefisien yang ditemukan. Koefisien determinasi dalam penelitian ini adalah $K D=$ $74,83 \%$ menunjukan interpretasi pengaruh tinggi atau kuat, hal ini berarti varian yang terjadi pada variabel $\mathrm{Y}$ (Hasil belajar matematika) 74,83\% 
ditentukan oleh varian yang terjadi variabel $\mathrm{X}$ (Kecemasan matematis). Dapat disimpulkan hubungan kecemasan matematis terhadap hasil belajar matematika adalah 74,83\%, dan sisanya $25,17 \%$ ditentukan faktor lain, seperti motivasi belajar matematika, kesulitan belajar matematika, dan masalah lain yang ada di sekolah.

Berdasarkan hasil observasi dan wawancara di kelas X IPS 1 sebagian besar siswa merasakan detak jantung yang tidak teratur, panik, khawatir, merasa tidak nyaman saat belajar matematika, dan sebagian besar siswa sulit memahami simbol-simbol matematika. Sehingga guru perlu mengantisipasi kecemasan matematis yang terjadi, agar hasil belajar yang diperoleh dapat maksimal. Sebagaimana yang dikemukakan oleh Zakaria (2008: 2007) kecemasan matematika adalah perasaan tegang, ketidakberdayaan, disorganisasi mental dan takut seseorang yang muncul ketika dihadapkan dengan persoalan manipulasi angka dan bentuk pemecahan masalah matematika. Dan yang terjadi dapat memicu reaksi-reaksi atau gejala-gejala pada umunya, kecemasan belajar matematika juga ditunjuk oleh gejala psikologis dan fisiologis. Kecemasan dengan intesitas wajar dapat dianggap memiliki nilai positif sebagai motivasi, tetapi apabila intensitasnya tinggi dan bersifat negatif dapat menimbulkan kerugian dan dapat mengganggu keadaan fisik dan psikis individu yang bersangkutan.Untuk mengatasi kecemasan siswa guru dapat menanamkan rasa percaya diri terhadap siswa bahwa mereka bisa mengerjakan dan belajar matematika lebih baik, dandapat memberikan latihan-latihan soal bertahap dari soal yang mudah, sedang, sukar sehingga siswa bisa mengerjakan soal-soal tersebut. Guru juga dapat menggunakan metode atau model pembelajaran yang bervariasi, memberikan suasana pembelajaran yang menyenangkan dan nyaman. Dari usaha yang dilakukan oleh guru diharapkan dapat mengurangi rasa cemas yang dirasakan siswa sehingga berdampak pada hasil belajar yang meningkat.

\section{KESIMPULAN}

Adapun kesimpulan pada penelitian ini adalah ada pengaruh negatif antara kecemasan matematis terhadap hasil belajar matematika siswa kelas X IPS 1 di SMA Negeri 1 Cisaat. Pengaruh negatif dalam penelitian ini yaitu jika kecemasan tinggi maka hasil belajar rendah begitu sebaliknya.

\section{DAFTAR PUSTAKA}

Agustiar, W. (2010). Kecemasan Menghadapi Ujian Nasional dan Motivasi Belajar pada Siswa Kelas XII SMA Negeri 10. Jurnal Psikologi. 8(1).

Ashcraft, M.H. (2002). Math Anxiety: Personal, Educational, and Cognitive Consequences. Dalam Current Directions in Psychological Science [Online]. Tersedia: http://cdp.sagepub.com/content/11/5/ 181.

Dimyati dan Mudjiono. (2013). Belajar dan Pembelajaran. Cetakan Kelima. Rineka Cipta. Jakarta.

Sudrajat. (2008). Pengertian Pendekatan, Strategi, Metode, Teknik dan Model Pembelajaran. Bandung: Sinar Baru Algesindo. 
Turmudi. (2008). Taktik dan Strategi Pembelajaran Matematika. Jakarta: Leuseur Cipta Pustaka.

Widyastuti, E. (2007). "Pengaruh

Kemampual Awal, Motivasi

Belajar, dan Kecemasan

Menghadapi Tes Matematika

Terhadap Prestasi Belajar

Matematika Siswa". [Skripsi].

Surakarta: Universitas Sebelas
Maret.

http//digilib.uns.ac.id/pengguna.ph $\mathrm{p} ? \mathrm{mn}=$ showview \&id=7185.

Zakaria, E. (2008). The Effect of Mathematics Anxiety on Matriculation Student as Related to Motivation and Achievement. Eurasia Journal of Mathematics, Science \& Technology Education. 